\title{
Relationship between Ecological Concepts and Biosafety in Broiler Breeder Farms
}

\section{author(s)}

Santos CA

Falconi FA ${ }^{2}$

Specialist in Food Quality Control, Biologist, GLOBOAVES AGRO AVÍCOLA LTDA augusto@globoaves.com.br

2 Assistant Professor - Pharmacy School UNIOESTE - fafalconi@terra.com.br

\section{Mail Address}

César Augusto dos Santos

GLOBOAVES Agro Avícola Ltda

Rod. BR-467, Km 03

85.811-750 - Cascavel, PR, Brasil

E-mail: augusto@globoaves.com.br

\section{- Keywords}

Avian biosafety, aviculture, broiler house, ecological modeling, ecology.

\section{ABSTRACT}

The entrance of poultry products into the trade world requires changes in the configuration of these products, such as programs that ensure their quality and biosafety for the consumers. This article aims at presenting new perception on poultry biosafety programs in broiler breeder farms from an ecological perspective, making these programs more efficient and cost-effective, i.e., more competitive. Using literature review, some convergences were found between ecology concepts and biosafety programs. One of these convergences is understanding the farm as an open ecosystem, integrating through adaptation the natural environment with the exotic environment. This also allows understanding how the production area interacts with the environment as to energy substrate input and output or as to the dissemination of poultry pathogens by vectors outside the farm or from the production area to the environment. This allows building a theoretical reference for further studies on ecological models for the improvement of poultry biosafety programs.

\section{INTRODUCTION}

During these first few years of the $21^{\text {st }}$ century, the poultry industry has faced a globalized market and high demand for products and services, which must comply to customers' requirements. In addition, companies must engage in sustainable development policies, and apply environmental and social management programs.

In the case of Brazil, the opening of new markets drove poultry production growth, increasing the requirements of the production process in order to produce better results. One of the new areas, which allowed higher productivity and lower production costs, was poultry house environment (Tinoco, 2001; Desouzart, 2004).

In Brazil, climate is very diverse, and the knowledge of regional and local characteristics is strategic for poultry production and health, demanding constant adaptations to industrial requirements. This limits the quality of this process, as well as customers' requirements, and therefore improvements need to be introduced (Scolari, 2001). One of these improvements is formalized in the biosafety program detailed in the National Plan of Poultry Health (Plano Nacional de Sanidade Avícola - PNSA) (Brasil, 2002), which established biosafety and health standards for poultry production and marketing for the domestic and foreign market.

A biosafety program consists of actions and measures aiming at improving poultry hygiene and health during the production process (COBB, 2003). This program becomes stricter as it goes up the pyramid of broiler production, from commercial farms to pure breed farms (Lauandos et al., 2005). According to Jaenisch (1998), the main issues 
of concern of the program are: chick acquisition, farm location, farm flow and transit, feed and water, cleaning and disinfection procedures, vaccination, and organic waste control. In addition, it is essential to serologically monitor birds for the control of possible contamination, as well as to control pathogens vectors, such as rodents, insects, and wild animals (Jaenisch, 1999; Lauandos et al., 2005).

In broiler breeder farms, biosafety programs are usually more efficient due to the presence of infrastructures, such as fences around the perimeter of the buildings, preventing the entrance of vehicles, people, and animals; entrance gate, with bathrooms and dressing rooms; room for the disinfection of materials (fumigator); vehicle disinfection area; input storage room; and organic waste disposal area, such as compost area (Antunes, 2004; Cobb, 2003; Gessulli, 2003). In addition, the space among poultry houses to ensure air circulation, the presence of a 'green belt' around the poultry houses (Tinoco, 2001), a production area with proper tools, machinery, and equipment ensure good environmental conditions that improve the production process and safety of farm products.

Standardized sanitation and disinfection procedures at farm level are suggested in PNSA (2002), as well as prophylactic control and biosafety standards, establishing actions to ensure flock health according to the risk of occurrence of diseases detected in Brazil, and recommended treatments (Brasil, 2002).

The ideal poultry house should be designed taking into account biosafety and environment in order to promote bird health and better productivity. However, technological advances in poultry production, driven by weather considerations, and present diseases, increased the dependence of the production process on control programs. These are often not appropriate for regional conditions, and therefore a more comprehensive understanding of the local environment is necessary to ensure the efficacy of biosafety programs.

\section{Biosafety programs of broiler breeder farms under an ecological perspective}

In broiler breeder production, there have been many improvements in programs related to management, such as biosafety. Biosafety in poultry production is defined as a way of understanding and ensuring flock health by means of standardized actions of production control in order to ensure final product quality (Kuttel, 2000). Broiler breeder farm biosafety regulations are described in the legislation of the National Plan of Poultry Health (PNSA) of the Brazilian Ministry of
Agroculture (Brasil, 2004)., which regulates the production process.

Several authors (Kuttel, 2000; Jaenisch, 1999; Lauandos et. al.,2005; Sesti, 2001, 2005; Guias Gessulli, 2003; Silva, 1999) consider the Biosafety Program associated to productivity and costs - as an efficient system for flock health prevention. However, the adaptation of the production system and of the bird population to the regional ecosystem must be taken into account. These authors highlight the importance of considering the ecological interactions with the natural fauna and flora by comprehensive pest and vector control actions, organic waste disposal, and delimitation of areas preventing the access of large animals. Such actions may prevent the contamination of flocks by pathogens.

The practical biosafety approach mentioned by Sesti (2005) structures poultry health control under political and economical issues, highlighting high productivity, low cost, and capacity to supply international markets. This understanding of poultry production may not ensure the efficacy of the standardized program, but may demonstrate control actions. According to Brasil (2004), poultry pathogen control policies promote actions for the treatment and the eradication of globally and locally important pathogens, such as bird flu and Newcastle disease, as well as mycoplasmosis and salmonellosis, which are characterized by both vertical and horizontal transmission.

According to Sesti (2005), vertical transmission is the contamination of the progeny by its progenitor, while horizontal transmission occurs during the entire production phase by means of several contamination factors. The authors considers that the only way to effectively control health flock is to apply a "biosafety program" under the perspective of "preventive veterinary medicine" in each step of the production process. In broiler breeder production, flock health control aims mainly to reduce mortality, to increase egg production and fertility - which directly influence production costs -, and to ensure human health, by preventing the transmission of zoonotic agents, such as Salmonella spp., and Campylobacter jejuni).

Sesti (2005) describes the hierarchical structure of the Poultry Biosafety Program as divided in conceptual biosafety, structural biosafety, and operational biosafety, which must be incorporated from poultry house design up to rearing. The analysis of these steps reveals that this program takes into account the relationship of microorganisms present in the production area with the environment. 
Different microorganisms may related to each other by means of inter-specific relationships or by coevolution, characterizing an ecological interaction among different populations within a community (PintoCoelho, 2000). The community is integrated to an ecosystem, where the abiotic and the biotic environment may relate to each other as an open system, i.e., system inputs and outputs (Odum, 1988) are included in the local ecological development. Based on these concepts, a broiler breeder farm may be considered as a recent ecosystem being adapted to the natural environment, and therefore, it is included in an ecological development process of ecosystems.

The adaptation of exotic and natural populations by co-evolution may be related to an ecological succession process, which starts with deforestation and in the landfill of the natural area (Odum, 1988). As proposed by Sesti (2005), when planning of implementation of a poultry farm, conceptual biosafety includes the choice of region and area size and location based on climate, soil, isolation vegetation characteristics, safety distance from pathogen transmission risks, and quantitative potential of safe housing as affecting local economy and health.

After planning, facilities to house the birds are built. The poultry house provides excellent environmental conditions and food availability, which attract other wild or domestic species in the surroundings. Structural and operational biosafety measures, such as screens to prevent the entrance of wild birds, closed silos for feed storage, automatic feeding systems to decrease feed wastage, and pest and vector control plan must be put in place (Sesti, 2005; Kuttel, 2000; Guias Gessulli, 2003).

Other areas supporting herd health control are also essential for a biosafety program, such as showers and dressing rooms, room for tool disinfection, egg storage room, fumigators, egg cleaning and disinfection area. Inside the poultry house, there must be an area for collection tool handling, pre-disinfection, egg selection area, an area for feed distribution and weighing, electric and water controls. In addition, routine cleaning and disinfection processes are extremely important to reduce the risk of contamination of the system by pathogens (Sesti, 2005).

Biosafety, considered as a program to ensure poultry health, must take into account the presence of vectors and pathogenic microorganisms, which live in the same environment as broiler breeders or inside the birds. The practical demonstration of the ecological relationship between the farm and the environment may contribute for the implementation of biosafety programs in broiler breeder farm, based on the ecological assumption included in its norms and control suggestions.

\section{Modeling for a process of ecological interactivity between the farm and the natural environment, as considered in a biosafety program}

As previously mentioned, when a facility is inserted in the environment, the impact destroys the natural harmonic structure of the fauna and the flora, resulting in a new ecological reality. According to Odum (1988), environment destruction causes the ecological succession of populations in communities, with negative effects to the natural taxa, in which population correlation tends to harmony in time. Therefore, the anthtopic environment behaves in the adaptation process as an open ecosystem.

Sesti (2005) considers broiler breeder farms according to this ecological development, particularly when planning control action to ensure neutrality between energy output and pathogenic input in the context of biosafety.

According to Cristoforletti (1999), Odum (1988), and Pinto-Coelho (2000), the relationships between the exotic environment and the natural environment are influenced by the cyclic adaptation of energy and biomass.

When the biosafety proposal of Sesti (2005) is considered under this perspective, the farm can be considered as an energy source both for microorganisms (pathogenic or not to poultry) and for large animals, through dead bird disposal, feed residues, litter and egg residues in areas accessible to these potential vectors. This clearly characterizes an ecological relationship, in which the fauna and the flora are considered as part of the process of reintegration of nutrients derived from the production to nature by means of decomposition and/or consumption of farm organic matter. The model adapted from Odum (1988) is shown in Figure 01, representing the basic structure of a system with an input source, system properties, and the interactivity between these properties and the final product (output).

Based on Figure 01 (concept of ecological modeling) and on SESTI's suggestion (2005) as to biosafety programs, when testing the influence of poultry production process energy substrate flow on surrounding natural biota, feed $(E)$ is considered the primary substrate for broiler breeder consumption (P1), which is transported (F1) to the poultry house as raw 


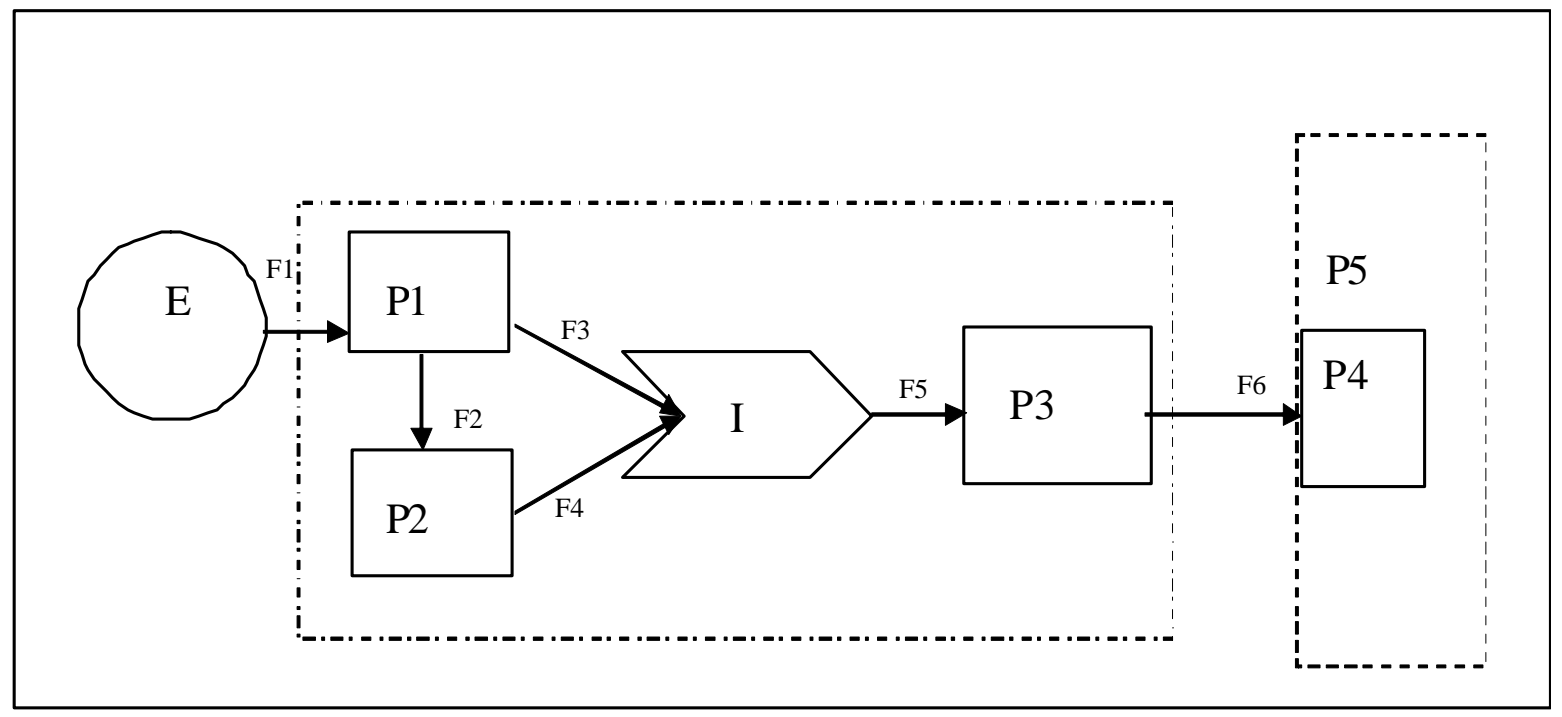

Fig. 01 - Diagram of the basic characteristics of a system. Modified from Odum (1988).

$E=$ source

P= property => P1 (feed); P2 (litter); P3 (pathogenic microorganisms); P4 (organic fertilizer); P5 (environment).

$\mathrm{I}=$ Compost

$F=$ flow => F1 (transport); F2 (waste); F3 (selection); F4 (residues); F5 (organic matter); F6 (disposal).

material for fertile egg production and for bird energy maintenance. Part of the feed is disposed on the litter (P2) or as waste due to the bird eating behavior (F2) or equipment failure in the service area.

One step of management is to select birds and eggs that do not comply to productivity or egg quality standards (F3), which, along with cleaning and litter residues (F4) are processed by composting (I). The organic material (F5) to be decomposed will be disposed as a farm byproduct in proper facility and under standardized management, resulting in a reduction of pathogenic microorganisms (P3) (Costa et al.; 2006).

Disposal (F6) of the organic waste derived from production processes is considered adequate when it is returned to the environment as organic fertilizer (P4), and incorporated to the energy process of the local flora and fauna.

Energy substrate derived from the production environment can also be incorporated by the local flora and fauna through the invasion of the production area by wild animals. This is foreseen in the biosafety program, which includes operational regulations for its control (Brasil, 2002).

In terms of risks of contamination of the process described in the diagram of basic characteristics of a system (Fig. 01), it is considered that pathogenic microorganisms may be introduced and grow or be transmitted to birds during all property steps $(P)$. This may occur by the introduction of contaminated feed, housing sick birds, or through residues that should have been disposed. As a second step, pathogens that were introduced in the natural environment may be retransmitted to the birds or to the facilities by vectors. These hypotheses warrant further studies analyzing Sesti's (2005) proposed biosafety program under the ecological perspective.

\section{Ecological consideration of the transmission of pathogenic microorganisms}

An animal is considered a vector when it is able to carry over microorganisms, pathogenic or not, to birds in any environment of poultry production. Examples are Salmonella spp., Mycoplasma, Newcastle disease virus, etc.

The most prevalent Salmonella species, mentioned by the biosafety program (Sesti, 2001), are included in regulation/DAS n.3 of 9/01/2002 of MAPA (Brazilian Ministry of Agricuture), such as Salmonella gallinarum, Salmonella enteritidis, Salmonella pullorum, and Salmonella typhimurium (Brasil, 2002). According to Back (2004), Salmonella can be found in "feces, internal organs, eggs and embryos of sick or healthy carriers, litter, facilities, equipment, feed, feed ingredients, and in domestic and wild animals." Newcastle disease is caused by the invasion of respiratory and intestinal mucosa invasion by Paramyxovirus, which main vectors 
are different materials and pieces of equipment, feed trucks, and any vehicles entering the farm.

Mycoplasma is another source of concern, transmitted both vertically and horizontally, and it is considered by Back (2004) "...difficult to treat and to control."

Many actions relative to pathogenic and natural contaminants are standardized by the Brazilian legislation (Brasil, 2002); however, regional contamination risk is not considered, allowing environmental contamination, and consequently, transmission of pathogens to the facilities, as mentioned above. This may cause increase of environmental infection load, and subsequent contamination of the facilities and of the birds in the production system.

When ecological coexistence between the farm and the environment was assessed under the concept of ecological system modeling adapted from Odum (1988) (Fig.01), we observed that it was possible to test energy substrate flow, and to understand the farm as an open system using some concepts suggested by Sesti's biosafety program (2005).

The conceptual biosafety program also allows considering both the interference of nature on the process of fertile egg production, and of the farm on the environment, which is implicit in regulations and suggestion for the control of flock health.

Therefore, it is possible to conclude that there are advantages of using this open system ecological model (Fig. 01), which is an innovative perspective for the poultry industry. It allows predicting health risks when designing the poultry house or when placing a broiler breeder flock, indirectly contributing for the development of the national poultry industry in terms of biosafety, ensuring safe, high-quality, and more competitive products in the world poultry market.

\section{REFERENCES}

Antunes R. Ecologicamente correto, economicamente viável. Avicultura Industrial 2004; (8):18-22.

Back A. Manual de doenças das aves. São Paulo: Editora Coluna Saber; 2004.

Brasil. Ministério da Agricultura e do Abastecimento, Secretaria de Defesa Agropecuária. Legislação de defesa sanitária animal avicultura: programa nacional de sanidade avícola. Brasília: Ministério da Agricultura e do Abastecimento; 2002. [citado 2005 out. 18]. Disponível em: http://www.agricultura.gov.br/portal/ page?_pageid=33,981919\&_dad=portal\&_schema=PORTAL.
Brasil. Ministério da agricultura e do abastecimento 2004. União Brasileira de Avicultura: Objetivos do PNSA. [citado 2006 set 20]. Disponível em: http://www.uba.org.br/pnsa_objetivos.html.

Christofoletti A. Modelagem de sistemas ambientais. São Paulo: Edgard Blücher; 1999.

Cobb-Vantress. COBB 500 guia de manejo de matrizes. Guapiaçu, SP:COBB; 2003

Costa MSSM, Costa LAM, Pelá A, Silva CJ, Decarli LD, Uilson FM. Desempenho de quatro sistemas para compostagem de carcaça de aves. Revista Brasileira de Engenharia Agrícola e Ambiental 2006; 10(3):692-698.

Desouzart O. A evolução do mapa mundi avícola. Ave World 2004; 2(10):24-32

Guias Gessulli. Vacinas e vacinação na produção avícola. Porto Feliz, SP: Editora Ceva; 2003.

Jaenisch FRF. Aspectos de biosseguridade para plantéis de matrizes de corte. Embrapa Suínos e Aves, 1999. [citado 2005 nov 30]. Disponível em: http://www.cnpsa.embrapa.br/sgc/sgc_publicacoes/ itav011.pdf.

Jaenisch FRF. Biossegurança e cuidados sanitários para frangos. Embrapa Suínos e Aves, 1998. [citado 2005 nov 30]. Disponível em: http://www.cnpsa.embrapa.br/sgc/sgc_publicacoes/ itav006.pdf.

Kuttel JA. Analisis de riesgos y puntos criticos de control (HACCP) em biosseguridade avicola. Entre Rios, AR: Artes Gráficas Yusty S.R.L.; 2000

Lauandos IP, Kondo N, Lima EA. A Biosseguridade exigida em granjas de avós e matrizes. Avicultura Industrial 2005; (8):22-31.

Odum EP. Ecologia. Rio de Janeiro: Editora Guanabara Koogan; 1988.

Pinto-Coelho RM. Fundamentos em ecologia. Porto Alegre: Artmed Editora; 2000

Scolari TMG. Biosseguridade na produção avícola. [citado 2005 out 28]. Disponível em: http://www.cnpsa.embrapa.br.

Sesti LAC. Biosseguridade em granjas reprodutoras. In: Macari M, Mendes AA. Manejo de matrizes de cortes. Campinas: FACTA; 2005. p.243-317.

Sesti LAC. Filosofia e conceitos de biosseguridade e doenças com potencial de riscos para a avicultura brasileira. In: Conferência APINCO de Ciências e Tecnologia Avícolas; 2001; Campinas,BR. Campinas: FACTA; 2001. p.47-86.

Silva PL. Programa de sanidade para matrizes. In: Conferência APINCO'99 de Ciência e Tecnologia Avícolas; 1999; Campinas, BR. Campinas: FACTA; 1999. p.103-122.

Tinoco IFF. Industrial aviculture: new concepts of materials, conceptions and constructive techniques available for brazilian poultry houses. Revista Brasileira de Ciência Avícola 2001; 3(1):01-26. 